\title{
DISGENESIA DO HÍBRIDO EM POPULAÇÕES \\ NATURAIS DE Drosophila melanogaster.
}

Chirlei Cintia Klein, Liliana Essi

Acadêmicas do Curso de Ciências Biológicas-UFSM e Bolsista PET/CAPES Ronaldo Medeiros Golombieski

Acadêmico do Curso de Ciências Biológicas UFSM e Bolsista PIBIC/CNPq Élgion Lúcio da Silva Loreto

Departamento de Biologia - CCNE UFSM - Santa Maria, RS

\section{RESUMO}

Disgenesia do híbrido é definida como uma síndrome de traços genéticos aberrantes que são induzidos na progênie de certos cruzamentos entre linhagens de Drosophila melanogaster. O principal objetivo deste trabalho foi classificar as linhagens recém coletadas quanto ao potencial de atividade do elemento $P$ e sua habilidade regulatória a elementos provenientes de linhagens controles Harwich. Nossos resultados para populações naturais coletadas no Rio Grande do Sul, Brasil, e Colômbia, mostram que estas são do tipo $Q$, uma vez que todas as linhagens testadas são portadoras do elemento $P$, por critérios moleculares, e apresentaram uma atividade baixa de $P$. Do mesmo modo, tais linhagens mostraram-se pouco suscetíveis à ação do elemento $P$. Valores maiores de suscetibilidade e atividade foram encontradas na população colombiana, 
concordando com a hipótese da distribuição clinal da atividade deste elemento.

\section{ABSTRACT}

Hybrid dysgenesis has been defined as a remarkable sindrome of correlated genetic traits that are produced in some particular crosses between certain strains. The present study main objective was classify recently collected Drosophila melanogaster strains in relation to $P$ element activity and regulatory capacity. Our results to natural populations trapped from Rio Grande do Sul, Brazil and Colombia shows that it fell on $Q$ class, since all examinated strains has showed $P$ elements by molecular analysis and low $P$ activity. In the same way, these strains shows low susceptibility to $P$ element action. The bigger values found in the colombian population are in agreement with the clinal hypothesis to $P$ element activity.

\section{INTRODUÇÃO}

Disgenesia do híbrido em Drosophila melanogaster é definida como uma síndrome de traços genéticos aberrantes que são induzidos na progênie de certos cruzamentos entre linhagens desta espécie. Neste fenômeno pode-se observar a ocorrência de esterilidade parcial ou total, quebras cromossômicas, altas taxas de mutações, reversão de mutações e recombinações em machos. (SVED, 1976; KIDWELL e KIDWELL, 1976). A Disgenesia é causada pela mobilização de elementos de transposição, que são seqüências de DNA capazes de moverem-se no genoma.

Três sistemas de disgenesia independentes são descritos para 
D. melanogaster. Destes, a disgenesia gonadal $P-M$ ocorre quando machos de uma linhagem $P$, que possui o elemento de transposição $P$ em seus genomas, são cruzados com fêmeas de uma linhagem $M$, sem estes elementos. Nas linhagens $P$, a transposição é inibida por fatores citoplasmáticos transmitidos maternalmente, estado chamado de citótipo $P$. As linhagens que apresentam suscetibilidade à transposição de $P$ são ditas de citótipo M. Segundo ENGELS (1989), podemos classificar as linhagens em 4 classes: $P$ (possui citótipo $P$ e elementos $P$ ativos ), $M$ (nenhuma cópia do elemento $P$ é encontrada no genoma e possui o citótipo $M$ ), $M^{\prime}$ (possui citótipo $M e$ algumas cópias de elementos defectivos no genoma) e $Q$ (citótipo $P$ e cópias defectivas de elemento $P$ no genoma).

Todas as linhagens mantidas em laboratório desde 1950 são do tipo $M$. Porém as linhagens vão gradualmente se tornando possuidoras deste elemento de transposição a partir deste período. No meio da década de 80 , todas as linhagens coletadas já possuiam alguma cópia de elemento $P$. Acredita-se que este transposon invadiu o genoma de $D$. melanogaster por transmissão horizontal a partir de D. willistoni (BREGLIANO e KIDWELL, 1983).

Os elementos de transposição são ubíqüos e abundantes no genoma de todos os organismos, e fortes evidências apontam para um importante papel destes durante o processo evolutivo (KIDWELL e LISCH1997). Desta forma, estudos sobre a dinâmica e a atividade dos transposons em populações naturais podem contribuir para o esclarecimento da função dos elementos transponíveis no processo evolutivo. O principal objetivo deste trabalho foi classificar linhagens, recém coletadas, quanto ao potencial de atividade $P$ e sua habilidade regulatória a elementos provenientes de linhagens controles $(P)$. 


\section{MATERIAL E MÉTODOS}

\section{1- Linhagens utilizadas}

As seguintes linhagens de Drosophila melanogaster foram usadas como controle nestes experimentos: Harwich (linhagem $P$ ); Canton $S$ (linhagem M) ; Ry509 (linhagem M) que foram gentilmente cedidas pela Dra. Vera V. Gaiesky (UFRGS). As populações naturais (linhagens recentemente coletadas) utilizadas para verificar a presença, capacidade de transposição e suscetibilidade à transposição do elemento $P$ foram: Ibaguê(Coletada em Ibaguê-Colômbia- Janeiro de 1996 por Ruben Toro); Teutônia (Coletada em Teutônia-RS - Abril de 1997 por C. Klein); S. Pedro (Coletada em São Pedro do Sul-RS - Abril de 1997 por L. Essi); S. Ângelo (Coletada em Santo Ângelo-RS - Novembro de 1997 por R. Golombieski).

\section{2 - Manutenção dos estoques.}

Os estoques de Drosophila foram mantidos a $20^{\circ} \mathrm{C}$, em meio de cultura preparado a partir de uma mistura estoque constituída de $2 \mathrm{Kg}$ de farinha de milho, $280 \mathrm{~g}$ de germe de trigo, 1 xícara de açúcar, 3 colheres de sopa de leite em pó, 1 colher de sopa de sal. Para cada $250 \mathrm{~g}$ desta mistura acrescentamos $750 \mathrm{ml}$ de água e 1 grama de Nipagime dissolvido em $10 \mathrm{ml}$ de etanol comercial. Cozinha-se aproximadamente 15 minutos, após distribui-se nos vidros de cultura e autoclava-se por 15 minutos.

Para os testes de Disgenesia Gonadal, as moscas foram transferidas para câmara com temperatura controlada a $29^{\circ} \mathrm{C}$.

\section{3- Teste de disgenesia gonadal.}

Dois diferentes cruzamentos diagnósticos foram utilizados para avaliar as populações naturais em estudo quanto à atividade do elemento $P$ e quanto ao citótipo. O primeiro emprega fêmeas $M$ (Ry 509 ou Canton S) e 
machos em teste e avalia o potencial das linhagens para induzir traços disgênicos. Neste teste, quanto maior o índice de disgenesia quantificado, tanto maior é o potencial de atividade do elemento $P$ da linhagem testada. $O$ segundo envolve machos Harwich $(P)$ e fêmeas em teste e avalia a habilidade regulatória frente aos elementos $P$ muito ativos presentes no genoma da linhagem Harwich. Neste caso, quanto maior o índice de disgenesia, maior a suscetibilidade de tais linhagens à transposição do elemento $P$.

Após a eclosão da $F 1$, as moscas foram transferidas para um meio de cultura novo e mantidas por 3 dias para completa maturação das gônadas. Posteriomente, foram dissecadas em lupa entomológica e o número de gônadas disgênicas foi quantificado. Usou-se o teste do $\chi^{2}$ para a análise estatística.

\section{4 - Determinação molecular da presença do elemento $P$ por PCR.}

Para determinar as linhagens portadoras de elemento $P$, por critérios moleculares, usamos a Reação em Cadeia da Polimerase (PCR).

O DNA das diferentes linhagens foi extraído segundo JOWETT (1986). Para a reação de PCR, aproximadamente 100 ng de DNA foram acrescidos em $25 \mu \mathrm{l}$ de uma mistura de reação contendo $100 \mathrm{ng}$ de primers específicos para o elemento $P$ de $D$. melanogaster, 1unidade de Taq Polimerase, $200 \mathrm{mM}$ de dNTPs. Usamos os seguintes primers: $P_{1775}$ 5'TGCTTCGCTTGATGGCTT 3'; P2302 5' CCAACTCATCCATTTCGGT 3'; $P_{2863}$ 5' TCGGCAAGAGACATCCA 3'. O par de primer $P_{1775}$ e $P_{2302}$ amplifica um fragmento de $0,5 \mathrm{~kb}$. $O$ par de primer $P_{1775}$ e $P_{2863}$ amplifica um fragmento de $1,1 \mathrm{~kb}$. A reação consistiu de 30 ciclos a $94^{\circ} \mathrm{C}, 30$ s como fase de desnaturação; $60^{\circ} \mathrm{C}, 30$ s para anelamento e $72^{\circ} \mathrm{C}, 60$ s para extensão. Os produtos das reações foram observados em gel de agarose $0,8 \%$, corados com brometo de etídio, em transluminador UV. 


\section{RESULTADOS}

\section{Cruzamentos controles}

Os cruzamentos entre machos Harwich $(P)$ e fêmeas das linhagens $M$, Canton S e Ry509, apresentaram $100 \%$ de indivíduos na F1 com gônadas normais quando mantidas a $20^{\circ} \mathrm{C}$, mas altas taxas de disgenesia quando mantidas a $29^{\circ} \mathrm{C}$ (ver Tabela 1). Estes dados indicam que as nossas condições de testes estavam adequados para detectar a disgenesia causada pelo elemento $P$.

Tabela 1: Cruzamentos entre machos Harwich e fêmeas de linhagens $M$

\begin{tabular}{|c|c|c|c|c|}
\hline & \multicolumn{2}{|c|}{ Macho Harwich X Fêmeas Ry509 } & \multicolumn{2}{|c|}{$\begin{array}{l}\text { Macho Harwich X Fêmeas Canton } \\
\mathrm{S}\end{array}$} \\
\hline & $20^{\circ} \mathrm{C}$ & $29^{\circ} \mathrm{C}$ & $20^{\circ} \mathrm{C}$ & $29^{\circ} \mathrm{C}$ \\
\hline $\begin{array}{l}\text { Individuos } \\
\text { normais }\end{array}$ & $190(100 \%)$ & $36(19,05 \%)$ & $140(100 \%)$ & $69(46,94 \%)$ \\
\hline $\begin{array}{l}\text { Indivíduos } \\
\text { disgênicos }\end{array}$ & 0 & $153(80,95 \%)$ & 0 & $78(53,06 \%)$ \\
\hline TOTAL & 190 & 189 & 140 & 147 \\
\hline
\end{tabular}

A maioria dos cruzamentos realizados entre as linhagens controles e as linhagens em teste, quando mantidos a $20^{\circ} \mathrm{C}$, resultaram em prole com as gônadas normalmente desenvolvidas (ver Tabelas 2, 3 e 4). Estes são os resultados esperados, uma vez que a esta temperatura o elemento $P$ não desencadeia o fenômeno da disgenesia. Gônadas 
disgênicas foram encontradas, ainda que em baixa freqüência, nos cruzamentos entre fêmeas Ry509 e machos das linhagens S. Pedro $(0,5 \%)$ e S. Ângelo (2.06\%) (ver Tabela 4).

Tabela 2: Cruzamentos entre machos Harwich com as linhagens testes a $20^{\circ} \mathrm{C}$

\begin{tabular}{|l|c|r|r|r|}
\hline $\begin{array}{l}\text { Cruzamentos com machos Harwich a 20C } \\
\text { descendentes }\end{array}$ & IBAGUE & TEUTÓNIA & S. PEDRO & S. ANGELO \\
\hline $\begin{array}{l}\text { Indivíduos } \\
\text { normais }\end{array}$ & $121(100 \%)$ & $107(100 \%)$ & 112 & $142(100 \%)$ \\
\hline $\begin{array}{l}\text { Indivíduos } \\
\text { disgênicos } \\
\text { TOTAL }\end{array}$ & 0 & 0 & $(100 \%)$ & 0 \\
\hline
\end{tabular}

Tabela 3: Cruzamentos entre fêmeas Canton S com as linhagens testes a $20^{\circ} \mathrm{C}$

\begin{tabular}{|l|c|c|c|c|}
\hline \multicolumn{5}{|c|}{ Cruzamentos com fêmeas Canton S a 20C } \\
\hline $\begin{array}{l}\text { descendentes } \\
\text { machos }\end{array}$ & IBAGUE & TEUTÓNIA & S. PEDRO & S. ANGELO \\
\hline $\begin{array}{l}\text { Indivíduos } \\
\text { normais }\end{array}$ & $120(100 \%)$ & $131(100 \%)$ & $\begin{array}{c}103 \\
(100 \%)\end{array}$ & $136(100 \%)$ \\
\hline $\begin{array}{l}\text { Indivíduos } \\
\text { disgênicos } \\
\text { TOTAL }\end{array}$ & 0 & 0 & 0 & 0 \\
\hline
\end{tabular}


Tabela 4: Cruzamentos entre fêmeas Ry509 com as linhagens testes a $20^{\circ} \mathrm{C}$

\begin{tabular}{|l|c|c|c|c|}
\hline \multicolumn{5}{|c|}{ Cruzamentos com fêmeas Ry509 a 20C } \\
$\begin{array}{l}\text { descendentes I| } \\
\text { machos }\end{array}$ & IBAGUÉ & TEUTONIA & $\begin{array}{c}\text { S. PEDRO } \\
.\end{array}$ & S. ÁNGELO \\
\hline $\begin{array}{l}\text { Indivíduos } \\
\text { normais }\end{array}$ & $120(100 \%)$ & $133(100 \%)$ & $\begin{array}{c}150 \\
(99,5 \%)\end{array}$ & $143(97,94 \%)$ \\
\hline $\begin{array}{l}\text { Indivíduos } \\
\text { disgênicos }\end{array}$ & 0 & 0 & $1(0,5 \%)$ & $3(2,06 \%)$ \\
\hline TOTAL & 120 & 133 & 151 & 146 \\
\hline
\end{tabular}

\section{Cruzamentos testes}

Os resultados obtidos revelam que o potencial de atividade de $P$ nas linhagens em teste é baixo, inversamente à sua habilidade regulatória que é alta. Os maiores valores de disgenesia em cruzamentos com fêmeas $\mathrm{M}$ a $29^{\circ} \mathrm{C}$ ocorreram nos cruzamentos entre as linhagens Ibaguê e Canton S, onde os casos de fenótipos disgênicos somaram 5,83\% do total de indivíduos dissecados (Tabela 6). Observou-se diferenças significativas de disgenesia para a linhagem Ibaguê $\left(\chi^{2}=9,15\right)$. A freqüência de gônadas disgênicas em cruzamentos com as fêmeas Ry509 e machos em teste foi baixa, sendo o maior valor observado de $2,12 \%$ para os cruzamentos com machos S. Pedro (Tabela 5), não havendo diferenças quando comparados pelo teste do $\chi^{2}$. Em cruzamentos a $29^{\circ} \mathrm{C}$ envolvendo machos $\mathrm{P}$, nenhum caso de disgenesia foi observado em cruzamentos com fêmeas S. Pedro e S. Ângelo. Os maiores valores de disgenesia foram observados em cruzamentos com fêmeas Ibaguê, onde a ocorrência de indivíduos 
disgênicos somou $17,92 \%$ do total de dissecados. Os cruzamentos com fêmeas Teutônia resultaram em 6,01\% de disgenesia. (Tabela 7).

Tabela 5:Cruzamentos a $29^{\circ} \mathrm{C}$ entre fêmeas Ry509 e machos em teste

\begin{tabular}{|c|c|c|c|c|}
\hline \multicolumn{5}{|c|}{ Teste atividade de P (cruzamentos com fêmeas Ry 509) } \\
\hline $\begin{array}{l}\text { Linhagens em } \\
\text { teste }\end{array}$ & IBAGUE & TEUTÓNIA & S PEDRO & S ÂNGELO \\
\hline $\begin{array}{l}\text { indivíduos } \\
\text { normais }\end{array}$ & $129(99,23 \%)$ & $427(98,16 \%)$ & $93(96,88 \%)$ & $147(100 \%)$ \\
\hline $\begin{array}{l}\text { Indivíduos } \\
\text { disgênicos }\end{array}$ & $1(0,77 \%)$ & $8(1,84 \%)$ & $3(2,12 \%)$ & 0 \\
\hline TOTAL & 130 & 435 & 96 & 147 \\
\hline
\end{tabular}

Tabela 6:Cruzamentos a $29^{\circ} \mathrm{C}$ entre fêmeas Canton $\mathrm{S}$ e machos em teste

\begin{tabular}{|l|c|c|c|c|}
\hline \multicolumn{5}{|c|}{ Teste atividade de P (cruzamentos com fêmeas Canton S) } \\
\hline $\begin{array}{l}\text { Linhagens em } \\
\text { teste }\end{array}$ & IBAGUE & TEUTÓNIA & S PEDRO & S ÂNGELO \\
\hline $\begin{array}{l}\text { Indivíduos } \\
\text { normais }\end{array}$ & $97(94,17 \%)$ & $102(97,14 \%)$ & $170(98,27 \%)$ & $\begin{array}{c}120 \\
(99,17 \%)\end{array}$ \\
\hline $\begin{array}{l}\text { Indivíduos } \\
\text { disgênicos }\end{array}$ & $6(5,83 \%)$ & $3(2,83 \%)$ & $3(1,73 \%)$ & $1(0,83 \%)$ \\
\hline TOTAL & 103 & 105 & 173 & 121 \\
\hline
\end{tabular}


Tabela 7:Cruzamentos a $29^{\circ} \mathrm{C}$ entre machos Harwich e fêmeas em teste

\begin{tabular}{|l|c|c|c|c|}
\hline \multicolumn{3}{|c|}{ Teste suscetibilidade a P (cruzamentos com machos Harwich) } \\
$\begin{array}{l}\text { Linhagens em } \\
\text { teste }\end{array}$ & IBAGUE & TEUTONIA & S. PEDRO & S ANGELO \\
$\begin{array}{l}\text { Indivíduos } \\
\text { normais }\end{array}$ & $87(82,07 \%)$ & $172(93,99 \%)$ & $209(100 \%)$ & $142(100 \%)$ \\
$\begin{array}{l}\text { Indivíduos } \\
\text { disgênicos }\end{array}$ & $19(17,93 \%)$ & $11(6,01 \%)$ & 0 & 0 \\
\hline TOTAL & 106 & 183 & 209 & 142 \\
\hline
\end{tabular}

\section{Análise Molecular por PCR da presença do elemento $\boldsymbol{P}$ nas populações}

A amplicação dos fragmentos de DNA de tamanho correspondente ao esperado ocorreu para as linhagens Harwich, São Pedro do Sul, Ibaguê, Santo Ângelo e Teutônia. Não houve amplificação nas linhagens Canton S e Ry509. (Figura 1). Além da banda de tamanho esperado (1.1 Kb), uma banda de tamanho menor foi observada na linhagem S. Ângelo, indicando que esta linhagem deve possuir algumas cópias de elementos deletados para esta região do elemento. 


\section{$\begin{array}{lllllllllll}1 & 2 & 3 & 4 & 5 & 6 & 7 & 8 & 9 & 10\end{array}$}

Figura 1: Amplificação por PCR do fragmento de $1,1 \mathrm{~kb}$ do elemento $P$.

1) Controle negativo (sem DNA); 2) Reação de PCR em que o DNA genômico da linhagem Harwich foi usado como molde; 3) Reação de PCR em que o DNA genômico da linhagem Harwich foi usado como molde; 4) Reação de PCR em que o DNA genômico da linhagem Teutônia foi usado como molde; 5) Reação de PCR em que o DNA genômico da linhagem $S$. Pedro foi usado como molde; 6) Reação de PCR em que o DNA genômico da linhagem Canton S foi usado como molde; 7) Reação de PCR em que o DNA genômico da linhagem Ibaguê foi usado como molde; 8) Reação de PCR em que o DNA genômico da linhagem Ry509 foi usado como molde; 9) Reação de PCR em que o DNA genômico da linhagem $S$. Ângelo foi usado como molde; 10) Fago $\lambda$ clivado com HindlII.

\section{DISCUSSÃO}

O elemento de transposição $P$ possui variados graus de atividade que estão relacionados com a própria estrutura do elemento, se este apresenta-se completo ou possui deleções internas. Outro fator que interfere na sua atividade é a habilidade regulatória dos citótipos das 
linhagens sobre as quais atua. Estes dois elementos básicos somados, ainda, a fatores ambientais e interações ecológicas são fatores fundamentais na regulação da atividade do elemento $P$.

A existência de linhagens de Drosophila melanogaster portadoras de elementos $P$ com variações em sua estrutura e atividade, e de citótipos diferentes possibilitou a classificação das linhagens de $D$. melanogaster nos 4 grupos já referidos: M, M', Q e P (ENGELS, 1989).

O que se tem observado é que estes grupos parecem seguir um padrão regular de distribuição. Vários modelos têm sido propostos para explicar a distribuição destes grupos no globo.

BOUSSY (1987) propôs o modelo da latitude clinal ao observar a ocorrência de uma espécie de barreira latitudinal na distribuição das características $P-M$. As linhagens $P$ tenderiam a ocorrer em regiões mais próximas do equador, linhagens $Q$ mais próximas dos trópicos e as linhagens $M$ ' e $M$ tenderiam a ocorrer em regiões de clima mais ameno, mais afastadas ainda dos trópicos.

KAPLAN et al (1985) propuseram o modelo degenerativo, segundo o qual há uma progressão do estado $M$ para $P, P$ para $Q$ e $Q$ para M' em populações que estão evoluindo quanto ao sistema $P$. Partiria-se da invasão da linhagem pelo elemento, seguindo-se do acúmulo de elementos $P$ defectivos, com tendência à escassez de elementos $P$ completos no genoma.

RUFO (1997) testou linhagens coletadas em diferentes regiões do Brasil quanto ao sistema P-M de disgenesia e constatou que as linhagens coletadas mais ao sul do Brasil possuem atividade de $P$ mais baixa do que as linhagens coletadas ao norte do país, seguindo uma variação clinal na distribuição. Ainda neste trabalho, RUFO constatou que a linhagem coletada no Rio Grande do Sul pertencia à classe $Q$, sendo a atividade de $P$ baixa na linhagen do $\mathrm{RS}$ e habilidade regulatória de $P$ alta.

Nossos resultados para as linhagens rio-grandenses 
concordam com os resultados obtidos por RUFO, sendo as linhagens consideradas, também, do tipo Q.

Como todas as linhagens testadas são portadoras do elemento $P$ por critérios moleculares, nenhuma destas linhagens poderia ser $M$. Também não poderiam ser $P$, já que todas elas apresentaram uma atividade baixa de $P$. Do mesmo modo, tais linhagens não poderiam ser consideradas do tipo M' pois, apesar de baixa, apresentaram alguma atividade de $\mathrm{Pe}$ mostraram-se pouco suscetíveis à ação do elemento $P$.

Assim, todas as linhagens são do tipo $Q$, apresentando elementos $P$ por critérios moleculares, baixa atividade de $P$ e baixa suscetibilidade a $P$.

Apenas a linhagem Ibaguê testada neste trabalho, apesar de ser considerada uma linhagem tipo $Q$, mostrou maior suscetibilidade à ação de $P$ e maior atividade de $P$ comparada com as linhagens rio-grandenses, que possuem padrões de atividade e regulação do elemento $P$ semelhantes entre elas.

Os casos de disgenesia ocorridos a $20^{\circ} \mathrm{C}$ nos cruzamentos com fêmeas Ry509 e machos S. Pedro e S. Ângelo podem envolver a presença do elemento hobo, uma vez que a linhagem Ry 509 é do tipo E (BLACKMAN e GELBART, 1989).

A compreensão dos mecanismos que envolvem a suscetibilidade ao elemento, sua transposição e sua regulação no genoma é muito importante para o entendimento da evolução de tal elemento. E como a invasão do genoma de $D$. melanogaster é, ainda, um evento recente que tem sido observado nos últimos 30 anos, este momento torna-se especialmente propício para o estudo dos mecanismos de ativação, variação e silenciamento deste elemento. 


\section{BIBLIOGRAFIA}

BLACKMAN, R. e GELBART, W. Hobo elements in Drosophila melanogaster. In: BERG, D.E. \& HOWE, M.M. (ed). Mobile DNA. American Society for Microbiology, Washington, D.C., p. 523-529,1989.

BOUSSY, I.A. A Latitudinal cline in P-M gonadal dysgenesis potential in Australian Drosophila melanogaster populations. Genetic Research (Cambridge), 49:11-18,1987

BREGLIANO, J.C.e KIDWELL, M.G. Hybrid dysgenesis determinants. In: SHAPIRO, J.A. (ed) Mobile Genetic Elements, London, Academic Press, p.363-410, 1983.

ENGELS, W.R. $P$ elements in Drosophila melanogaster. in: BERG, D.E. \& HOWE, M.M. Mobile DNA, Washington, Amer. Soc. for Microb, 1989. JOWETT, T. Preparation of nucleic acids, in: Roberts D. B. (Ed.) Drosophila: a Practical Approach, IRC Press., Washington, DC, pp. 275-286, 1986. KAPLAN, N., DARDEN, T. e LANGLEY, C. Evolution and extinction of transposable elements in Mendelian population. Genetics, 109:459480, 1985.

KIDWELL, M.G. e LISCH, D. Transposable elements as sources of variation in animals and plants. PNAS 94: 7704-7711, 1997.

KIDWELL, M.G. e KIDWELL, J.F. Selection for male recombination in Drosophila melanogaster. Genetics 84: 333- 338, 1976.

RUFO, V.C., Disgenesia híbrida induzida pelos elementos transponíveis $P$ e Hobo em linhagens de Drosophila melanogaster de diferentes regiões brasileiras. Dissertação de mestrado apresentada ao Curso de PG em Ciências Biológicas da UNESP de São José do Rio Preto - SP, 1997. SVED, J.A. Hybrid dysgenesis in Drosophila melanogaster. a possible explanation in terms of spatial organization of chromosomes. Aus. J. Biol. Sci. 29:375-382, 1976. 